With regard to the second question, we have Sir Almroth Wright's work, which seems to show that tuberculin B.E. is a very good antigen for staphylococcal infections. I feel, therefore, that the therapeutic, non-specific effect of tuberculin is a matter that ought to be subjected to further scientific investigation.

\title{
REFERENCES
}

1. Wright, Sir Almroth.-Lancet, August 1, 8 and 15, 1931.

2. Lancet, March 10, 1923.

3. Rich and McCordock.-Bull. Johns Hopkins Hosp., No. 5, Vol. XLIV, May, 1929.

4. Rich and Lewis.-Proc. Soc. Exp. Biol. and Med., Vol. XXV, p. 596, 1928.

\section{HARDNESS OF THE EYE: AN HISTORICAL NOTE}

\author{
$\mathrm{BY}$ \\ ARNOLD SORSBY
}

LONDON

WHEN Brisseau ${ }^{1}$ established, in 1709 , that cataract was a change in the lens itself, and not an organised opacity in front of it, he also advanced the view that glaucoma, which up to then was regarded as dessication of the lens, was not a lesion of the lens at all, but a change in the vitreous. The clinical conception of glaucoma then prevailing was no less confused, and 150 years had to pass before the essential features of the disease were clearly recognised. The general recognition of such a thing as hardness of the eye had still to come, and its recognition as the characteristic sign of glaucoma was a very late achievement.

William Mackenzie ${ }^{2}$ is generally credited with establishing hardness as a feature of glaucoma. In his classical textbook (1st edition, 1830) he repeatedly stresses this association. He contrasts the blindness of glaucoma with that of cataract:

The eyeball in glaucomatous amaurosis always feels firmer than natural; while in cataract, it presents its usual degree of resistance to the pressure of the finger. (1st edition, p. 572.)

On the succeeding page (p. 573), he states, in discussing the cataractous eye :

A stony hardness of the eye denotes glaucoma.

$\mathrm{He}$ also recognised acute glaucoma, though this term is not employed in the first edition, making its first appearance in the 
second (1835). He gives a brief but vivid description of an acute attack, and adds :

After some time the inflammatory symptoms subside ... and instead of the preternatural hardness which it formerly presented (the eye) becomes boggy. (p. 707.)

Nowhere in the literature before Mackenzie is there such a clear recognition of hypertension as an essential characteristic of glaucoma, both acute and chronic. But the conception as a whole was by no means original with Mackenzie. It was, so to speak, very much in the air in the early decades of the 19th century. Fabini, ${ }^{3}$ in a Latin treatise published in Pesth in 1831 , also speaks of stony hardness in glaucoma.

Bulbi normali elasticitas in duritiem fere lapideam mutatur acceditque vasorum oculi raricositas.

Hardness as a feature of both developing and established glaucoma (acute glaucoma going on to absolute glaucoma) is clearly brought out in "Traité théorique et pratique des Maladies des Yeux," par M. le Dr. Weller, Paris, 1828, translated from the 3rd German edition, with additional notes by $\mathrm{L}$. Jallat. ${ }^{4}$ The description of hardness is not a French interpolation. It is original in the 3rd German edition of Weller's "Krankheiten des menschlichen Auges"5 (1826) though no such reference is found in the 1st German edition (1819), nor in its English version : "Manual of the Diseases of the Human Eye . . . G. C. Monteith" (1821).

But hypertension in glaucoma was known even before then. There is an excellent clinical description of glaucoma in its acute phase in A. P. Demour's Treatise ${ }^{6}$ of 1818 . Hardness is clearly recognised : le globe devient dur au toucher.

The earliest reference to hardness of the eye is said to date from 1745, occurring in J. $Z$. Platner, "Institutiones chirurgiae rationalis." He distinguishes two types of glaucoma-one due to swelling of the lens and capsule, in which group the eye becomes hard, and the other due to swelling of the vitreous, in which case the eye becomes soft.

Proximum his vitium in lente crystallina est, si ea cum suo velamento multum et ita intermescit, ut reliquae oculorum partes $a b$ ea premantur. Hoc his indiciis cognoscitur: oculis durus, digito renitens. ...

That the honour of first recognising hardness of the eye belongs to Platner is vouched for by no lesser authorities than $H$. SchmidtRimpler, J. Hirschberg and A. Terson. This, however, is not the case. The credit must be given to Richard Banister, who recognised hardness of the eye practically a century and a quarter earlier.

Richard Banister has received scanty justice at the hands of 
medical historians. Reputed, for mistaken reasons, to be the author of "A Worthy Treatise of the Eyes," published in 1622; it has been shown that he only edited it; perhaps, as a consequence, his own contribution, Banister's "Breviary of the Eyes," running to 112 pages, and making part of the composite volume in which the aforementioned "Worthy treatise" appears, has received but little attention. Yet it is obviously the work of an honest man and a careful observer. The whole composite volume, "A treatise of one hundred and thirteene diseases of the Eyes and Eye-liddes," has its pages unnumbered. In Banister's Breviary, a discussion on gutta serena appears after the verses on The fit time for couchi[ng] of Cataracts. Banister stresses the seriousness and almost complete hopelessness of gutta serena (blindness associated with a transparent pupil, as opposed to gutta obscura, in which blindness is associated with an obscured pupil). He had two successes, but many failures, in the treatment of gutta serena, and he goes on to say:

When it pleaseth God to inable my skill, that I understand a more perfect Cure for this dangerous disease, I will publish the meanes that are most effectual and approved, whereby the Practitioner and the Patient may be the lesse mistaken in their expectation, but according to my observation, I will shew my opinion, where most hope of Cure is: if the humour settled in the hollow Nerves, be growne to any solid, or hard substance, it is not possible to be cured ; which may be iudged of, foure wayes. First, if it be of long continuance. Secondly, if they see no light at all of the sun, fire or candle. Thirdly, if one feele the Eye by rubbing upon the Eie-lids, that the Eye be growne more solid and hard, than naturally it should be. Fourthly, if one perceive no dilatation of the Pupilla, then there is no hope of Cure. Contrariwise, if the sight hath beene lost but a small time, viz., a moneth or two, if the Eye be perceived soft and pliable, if there be any dilatio in Pupilla, though it can scarcely be perceived, yet there is some hope of Cure.

The Breviary published in 1622 is dated from Stamford, "the last of Iune," 1621. In the clear recognition of hardness of the eye, not only as a physical, but also as a prognostic sign of the utmost importance, Banister is thus 124 years before Platner. His observations, however, fell on sterile soil ; it was well over 200 years before his teaching became part of ophthalmic practice.

A peculiar passage appears in Peter Kennedy's Ophthalmographia or A Treatise of the Eye, London, 1713: "When the Cataract is come to the full Ripeness or Maturity. . . . the sights of Objects is now gone, but shadows of Light and Darkness they are still sensible of; if otherwise, there is but little hope of succeeding [in 
operation]; the common ways of tryal is to shut the Eye, and rubbing it a little with the Finger, immediately open it to Light, and observing the Pupil to contract it self is a good sign.

Although this Method is frequently used, yet I see no reason for rubbing; another way I think as good, such as putting the Hand before the Eye, and suddenly take it away, or putting the patient in a darkish part of the Room, and bringing him nearer to the Window or Light, and the pupil contracting as I've said, is a good sign. . . . If the Pupil contracts but slowly, it is a token of its being old and of very long continuance. ... If the Uvea [=Iris] have lost its Contraction and Dilatation, it's a very bad sign" (pp. 84-85).

This passage (and much more of the book) is obviously an elaboration of Banister. Banister's four rules (duration, perception of light, rubbing the eyelid and pupil reaction) are here given in a modified and, on the whole, better manner, though his observation on " rubbing upon the Eie-lids" seems to have been misunderstood. It is noteworthy that Kennedy speaks of it as a common practice ; yet it is not found mentioned anywhere in English literature before Mackenzie. Banister's observation on hardness of the eye seems to have become debased into "rubbing the eye" before testing the pupil reaction to light, and subsequently to have become discarded altogether.

\section{REFERENCES}

1. Brisseau, M.-Traité de la cataracte et du glaucome. Paris, 1709.

2. Mackenzie, W.-A practical treatise on the diseases of the eye. London, 1st edition, 1830 ; 2nd edition, 1835.

3. Fabini, J. T.-Doctrina de morbis oculorum, p. 231. Pesth, 1831.

4. Traité théorique et pratique des maladies des yeux, par M. le Dr. Weller, traduit de l'Allemand sur la 3e. edition par F. J. Riester; augmenté de notes par L. Jallat. Tome 1, p. 349. Paris, 1828.

5. Weller, C. H.-Die Krankheiten des menschlichen Auges. 3te Auflage, p. 295. Berlin, 1826.

6. Demours, A. P.-Traité des Maladies des Yeux. Tome 1, p. 470. Paris, 1818.

7. Platner, I. Z.-Institutiones Chirurgiae rationalis tum medicae tum manualis, p. 889. Lipsiae, 1745.

8. Schmidt-Rimpler, H.-In Graefe-Saemisch. 1te Auflage. Band 5, Theil III, p. 74. Leipzig, 1877. 2te Auflage. Band 6, Abth. 1, p. 140. Leipzig, 1908.

9. Hirschberg, J.-In Graefe-Saemisch. 2te Auflage. Band 14, Abth. 11, p. 307. Leipzig, 1911.

10. Terson, A.-Les premiers observateurs de la dureté de l'oeil dans le glaucome. Arch. d'Ophtal., Tome XXVII, p. 625, 1907.

11. Banister, R.-Breviary of the Eyes: In A treatise of one hundred and thirteen diseases of the Eyes and Eye-Liddes. The second time published. . . . London, 1622. 